\title{
Effect of Annealing Time on Microstructure and Properties of P91 Heat Resistant Steel SMAW Joint
}

\author{
Qingxian Hü ${ }^{a *}$, Chengge Wu ${ }^{b}$, Yongbin Wang ${ }^{c}$, Peng Liv ${ }^{c}$ (D), Hongju Fan ${ }^{c}$ \\ aJiangsu University of Science and Technology, School of Materials Science and Engineering, \\ Zhenjiang, P. R. China. \\ ${ }^{b}$ Shandong Jiaotong University, School of Construction Machinery, Jinan 250357, P. R. China. \\ 'Shandong Jianzhu University, School of Materials Science and Engineering, Jinan 250101, P. R.China.
}

Received: June 27, 2021; Revised: December 15, 2021; Accepted: January 13, 2022.

\begin{abstract}
The microstructure and properties of shielded metal arc welding (SMAW) joint of P91 heat-resistant steel annealed at different holding time were observed and analyzed. The results show that the martensite and residual austenite structures in the weld zone and coarse grain heat affected zone (CGHAZ) were transformed with the extension of holding time. After $760^{\circ} \mathrm{C}+4 \mathrm{~h}$ annealing, a large number of white rod-shaped precipitates appeared in the weld zone. The main components of precipitates were $\mathrm{Fe}, \mathrm{Cr}$, $\mathrm{Mn}, \mathrm{V}, \mathrm{Si}$, and a small amount of oxides appeared. After $760^{\circ} \mathrm{C}+5 \mathrm{~h}$ annealing treatment, relatively fine white granular precipitation appeared in the weld zone, and a large number of oxides and some precipitates have been dissolved. After $760^{\circ} \mathrm{C}+6 \mathrm{~h}$ annealing treatment, the precipitated phases were composed of $\mathrm{Fe}-\mathrm{Cr}, \mathrm{Fe}_{3} \mathrm{Si}$, Ni-Cr-Fe, $\mathrm{Fe}_{2} \mathrm{MnAl}$. Compared with the annealing treatment for $5 \mathrm{~h}$, the microstructure of the precipitated phase is fine and uniform, dispersion distribution of second phase particles, and the material mechanics is relatively stable.
\end{abstract}

Keywords: P91 heat-resistant steel, annealing, holding time, microstructure, precipitates.

\section{Introduction}

P91 heat-resistant steel is a kind of improved type martensite $9 \mathrm{Cr} 1 \mathrm{Mo}$ steel ${ }^{1,2}$. The steel is fabricated by adding $\mathrm{V}, \mathrm{Nb}, \mathrm{N}$ and other strengthening elements in the steel containing $\mathrm{Cr}$ and Mo elements. At the same time, the elements $\mathrm{S}$ and $\mathrm{P}$ which are easy to cause cracks are reduced, and the hot brittleness of steel is improved. The reduction of harmful elements improves the oxidation resistance of P91 heat-resistant steel tube $\mathrm{e}^{3-5}$. The microstructure of P91 heat resistant steel is mainly martensite and some ferrite. It has excellent performance in high temperature environment. It mainly includes the structure stability at high temperature, endurance strength and creep strength ${ }^{6,7}$. P91 heat resistant steel is widely used in superheater, reheater and main steam pipe of boiler because of its good comprehensive mechanical properties. However, in the actual welding production, the P91 heat-resistant steel joint has some defects, such as weld crack, slag inclusion and incomplete penetration at the root of the weld ${ }^{8-11}$. At present, researchers have carried out related studies on the welding process and post-welding heat treatment process of P91 heat-resistant steel ${ }^{12,13}$. From the point of view of the actual production and installation of thermal power supercritical units and supercritical units, the relationship between the holding time of P91 heat-resistant steel at different heat treatment temperatures and the change of joint structure and properties is very important. However, at present, there are few researches on the structure and performance based on the heat treatment process provided

*e-mail: qingxh200706@163.com by industry standards ${ }^{14-16}$, so further researches are needed. In these studies, the effect diffusible hydrogen in deposited metal, weld groove designs and post-weld normalizing and tempering (PWNT) heat treatments ${ }^{17}$ on microstructure and performance of P91 heat-resistant steel by SMAW were analyzed and discussed. However, under the premise of meeting the welding performance of P91 heat-resistant steel joints, the heat holding time of post-welding heat treatment can be shortened as far as possible, thus shortening the time of post-welding heat treatment in actual production, greatly saving energy and reducing production cost.

In this paper, the P91 heat-resistant steel pipe was used in 300MW thermal power unit, and was welded by shielded metal arc welding (SMAW). The proper annealing temperature after welding was also selected, and the microstructure and performance of welded joint under the different annealing conditions were analyzed. The results will be to optimize the heat treatment process of $\mathrm{P} 91$ heat-resistant steel provide important research basis.

\section{Experimental}

The base material used in this test is P91 heat-resistant steel pipe ( $10 \mathrm{Cr} 9 \mathrm{Mo} 1 \mathrm{VNb}$ ), the length is $200 \mathrm{~mm}$, the diameter is $45 \mathrm{~mm}$ and the inner diameter is $35 \mathrm{~mm}$. The chemical composition of the P91 heat-resistant steel tube and the chemical composition of the R507 filler rod are shown in Table 1. The P91 steel tubes are welded by SMAW. During the welding, the $\mathrm{V}$ groove with $60^{\circ}$ and multi-layer welding 
were used, and groove geometry and weld bead structure is shown in Figure 1.

During the test, a mechanical cleaning including oil, paint, scale, rust and burr will be used, and the samples near the groove within 15 20mm must be cleaned before SMAW. Before welding the samples also should be to preheat, and the preheat temperature is $150{ }^{\circ} \mathrm{C}$. The filling material of choice for SMAW welding is R507 filler rod. During welding, the interlayer temperature was maintained at $200 \sim 250{ }^{\circ} \mathrm{C}$. The specific welding process parameters of this test were shown in Table 2. The heat treatment of welding joint after the welding will be annealed, and the annealing temperature was $760 \pm 20^{\circ} \mathrm{C}$, and the holding time was $4 \mathrm{~h}, 5 \mathrm{~h}$, and $6 \mathrm{~h}$, respectively. Then the samples were air-cooled to room temperature. The heat treatment curve was shown in Figure 2.

The microstructure, hardness, scanning electron microscopy (SEM) and X-ray diffraction energy spectrum of the samples before and after heat treatment were analyzed. Metallographic structure test using corrosion agent is ferric chloride hydrochloric acid aqueous solution, the test equipment used are respectively Nikon Epiphot 300U/200 type horizontal metallographic microscope, $\mathrm{HV}-1000$ type hardness tester, JSM-6380LA type scanning electron microscope, D/ MAX$\mathrm{RC}$ type X-ray diffractometer.

\section{Results and Analysis}

\subsection{Effect of Annealing holding time on microstructure of CGHAZ}

The microstructure of coarse grain heat affected zone (CGHAZ) of P91 heat-resistant steel SMAW butt joint without annealing treatment is mainly composed of martensite and residual austenite (see Figure 3a). At this time, the typical lath martensite structure, the position of the lath bundle is obvious, there is a small amount of residual austenite, and the stress in the structure is high. As shown in Figure $3 b$, after $760^{\circ} \mathrm{C}+4 \mathrm{~h}$ annealing treatment, the microstructure of CGHAZ began to change into the needle like martensite structure, and the residual austenite was relatively less than that before annealing, and the residual stress disappeared at this time. As shown in Figure $3 \mathrm{c}$, after $760^{\circ} \mathrm{C}+5 \mathrm{~h}$ annealing treatment, the microstructure of CGHAZ is typical needle-like martensite structure. Compared with the grain size of $760^{\circ} \mathrm{C}$ annealing treatment for $4 \mathrm{~h}$, the grain size is further refined. As shown in Figure 3d, the microstructure of the CGHAZ is still the needle lamellar martensite structure, which has little change compared with the microstructure after $760^{\circ} \mathrm{C}+5 \mathrm{~h}$ annealing, and the amount of residual austenite becomes less.

The microstructure of the CGHAZ of SMAW joint after $760^{\circ} \mathrm{C}$ annealing is significantly changed. Before annealing, the microstructure of CGHAZ is coarse lath martensite. After annealing, the microstructure of CGHAZ changes into needle lamellar martensite. However, with the extension of holding time, the needle lamellar martensite becomes relatively uniform and small, and the residual austenite decreases. The reason for the microstructural transformation is that at high temperature. At this time, the critical shear stress of slippage is relatively low, so slippage is easy to occur. When cooling is fast, lath martensite is easy to form, and a large number of substructures are formed ${ }^{18}$. The phase change stress relaxes in a sliding manner. In the annealing process, the temperature is relatively low, and the twinning is more likely to occur than slip. As a result, the structure is more prone to acicular martensite transformation.

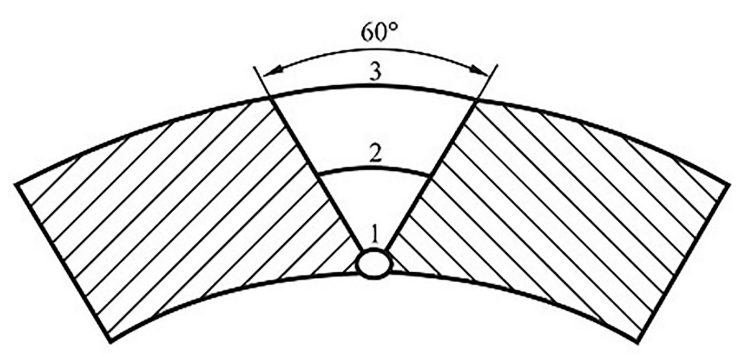

Figure 1. The geometry of the weld structure.

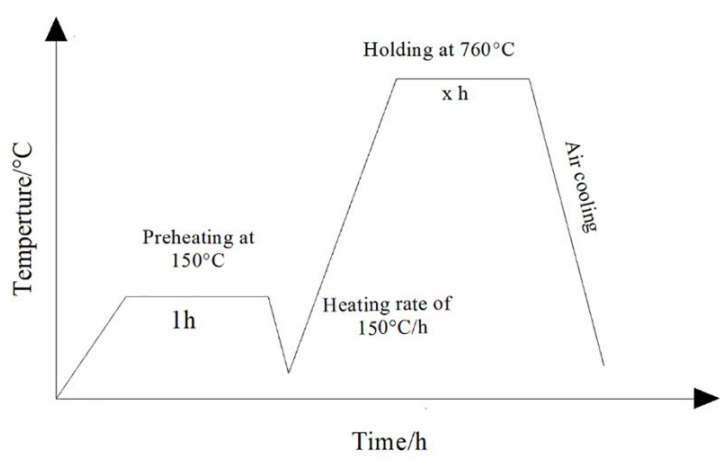

Figure 2. The process curve of the annealing treatment.

Table1. The chemical composition of P91 heat-resistant steel tube and R507 filler wire (wt.\%)

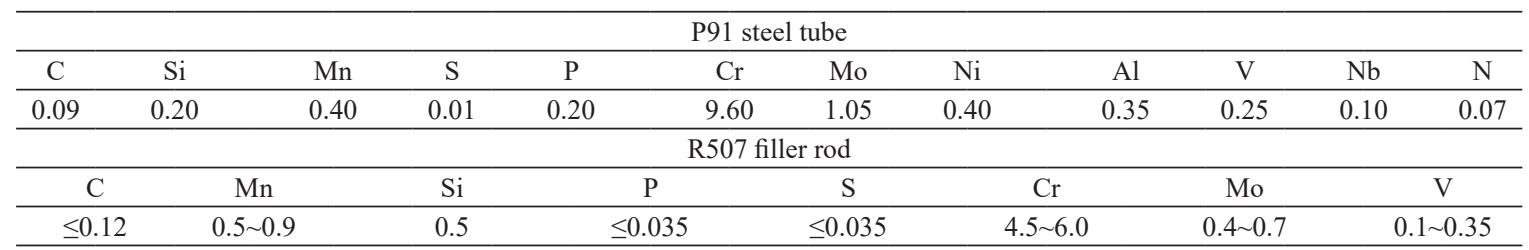

Table2. The welding parameters of SMAW welding for P91 heat-resistant steel tube

\begin{tabular}{ccccc}
\hline Layer & Diameter of filler wire (mm) & Welding current (A) & Arc voltage (V) & Welding speed (mm /s) \\
\hline $1-2$ & $\Phi 4.0$ & $100-150$ & $20-25$ & $15-20$ \\
\hline
\end{tabular}



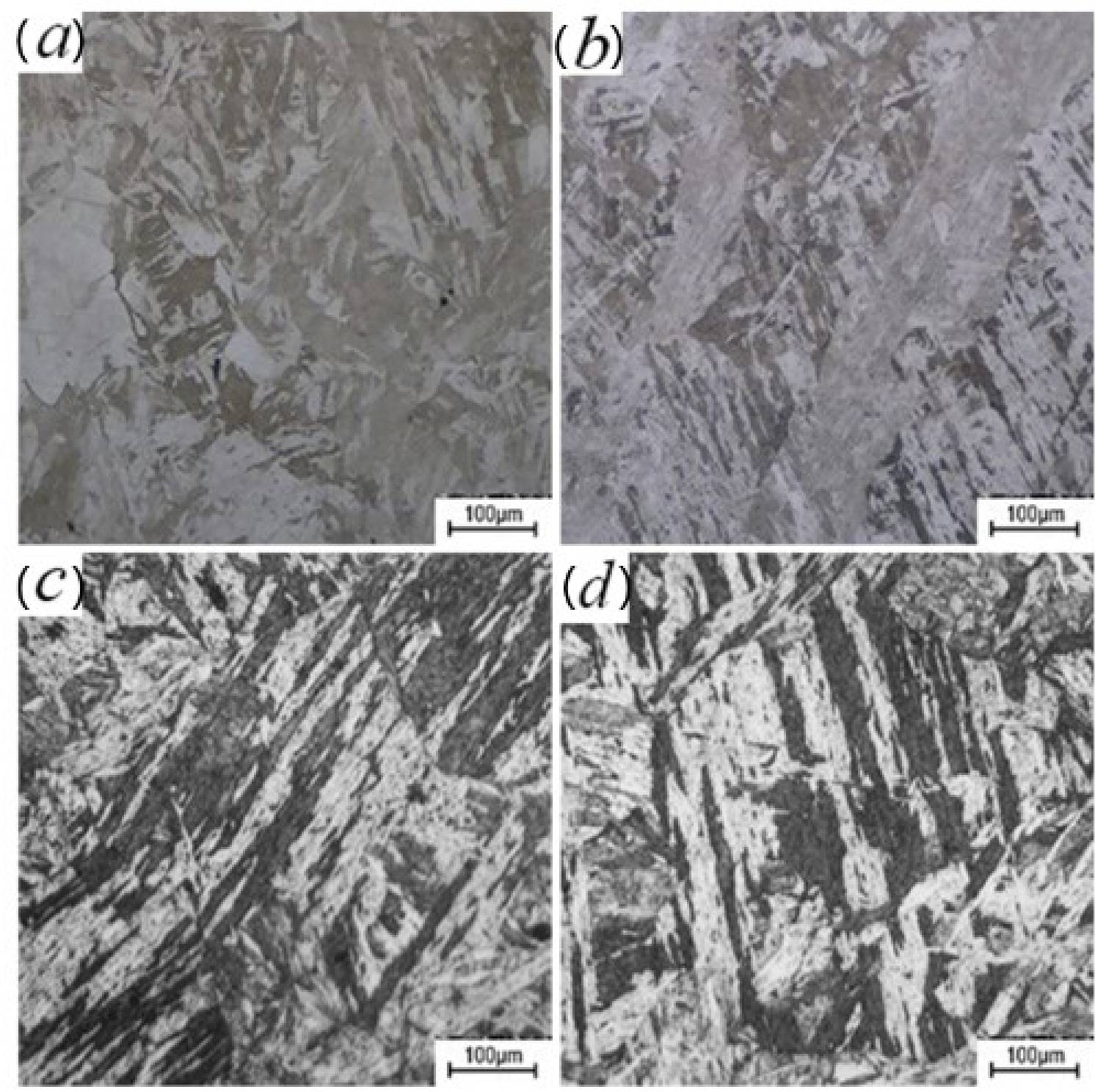

Figure 3. Microstructure in coarse grain heat affected zone (CGHAZ) under different holding time: (a) unannealed, (b) $760^{\circ} \mathrm{C}+4 \mathrm{~h}$, (c) $760^{\circ} \mathrm{C}+5 \mathrm{~h}$, and $(\mathrm{d}) 760^{\circ} \mathrm{C}+6 \mathrm{~h}$.

\subsection{Effect of annealing holding time on microstructure of weld zone}

As shown in Figure 4a, the weld area microstructure of unannealed P91 heat resistant steel is typical lath martensite. During the continuous cooling process after welding, the main structural transformation occurs from supercooled austenite to coarse lath martensite, and a small amount of residual austenite exists. As shown in Figure $4 \mathrm{~b}$, after $760^{\circ} \mathrm{C}+4 \mathrm{~h}$ annealing treatment, the microstructure of the weld area began to change into acicular martensite structure, and there was a certain amount of acicular martensite structure. Compared with before annealing, the residual austenite was relatively less, and the residual stress disappeared. As shown in Figure 4c, after $760^{\circ} \mathrm{C}+5 \mathrm{~h}$ annealing treatment, the microstructure of the weld area was typical needle-like martensite structure, and the grain size changed compared with that of $760^{\circ} \mathrm{C}$ annealing for $4 \mathrm{~h}$. As a result, the grain size was further refined. As shown in Figure 4d, the microstructure of the weld zone was still the needle-like martensite structure, which has little change compared with the microstructure after $760^{\circ} \mathrm{C}+5 \mathrm{~h}$ annealing, and the amount of residual austenite becomes less ${ }^{19}$.

The results of metallographic observation show that the microstructure of the weld zone of the SMAW joint changed significantly after $760^{\circ} \mathrm{Cannealing}$. Before annealing, the microstructure of the weld zone of the SMAW joint was a large lath martensite. After annealing at $760^{\circ} \mathrm{C}+$ for different time, the microstructure changed from lath martensite to acicular martensite and needle-lamellar martensite, and the microstructure became relatively uniform and fine. The change 

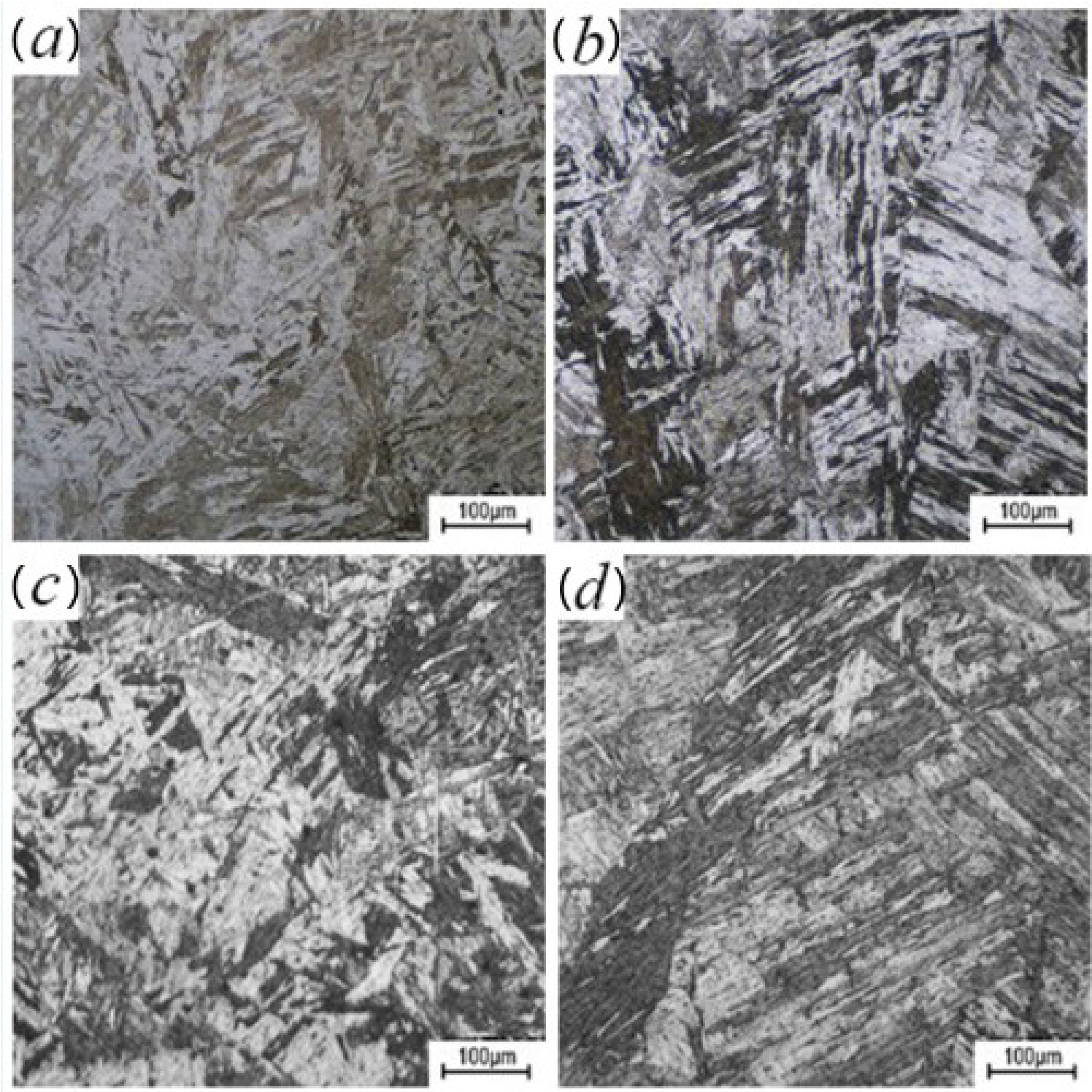

Figure 4. Microstructure in weld zone under different holding time: (a) unannealed, (b) $760^{\circ} \mathrm{C}+4 \mathrm{~h}$, (c) $760^{\circ} \mathrm{C}+5 \mathrm{~h}$, and (d) $760^{\circ} \mathrm{C}+6 \mathrm{~h}$.

of microstructure morphology was also related to the time of annealing and heat preservation.

\subsection{Effect of annealing holding time on hardness distribution of joints}

The microstructure analysis above indicates that the microstructure of each area of the SMAW welded joint changes significantly after annealing with different holding time. Therefore, the influence of microstructure change on the mechanical properties of the welded joint can be reflected by analyzing the hardness change. The microhardness was measured at a dozen positions on a straight line across the base metal from the heat affected zone to the weld zone. The results show that the hardness of the samples after annealing and holding is lower than that of the samples without annealing, and the microhardness of the heat affected zone and the base metal is obviously higher than that of the weld zone. The hardness value of CGHAZ fluctuated obviously and reached the peak value in the heat affected zone. In this experiment, four samples were taken to conduct microhardness tests respectively. Figure 5 shows the microhardness distribution test results of $\mathrm{P} 91$ heat-resistant steel SMAW butt joint before annealing and after annealing and different holding time.

According to the microhardness distribution curve of P91 heat-resistant steel welded joints, the overall hardness of the welded joints without annealing treatment is higher than that after annealing treatment, while the hardness distribution trend of the welded joints with different annealing holding time is similar. The hardness distribution trend of the welded joint is very different before and after annealing. Without annealing treatment, the maximum hardness appears in the 


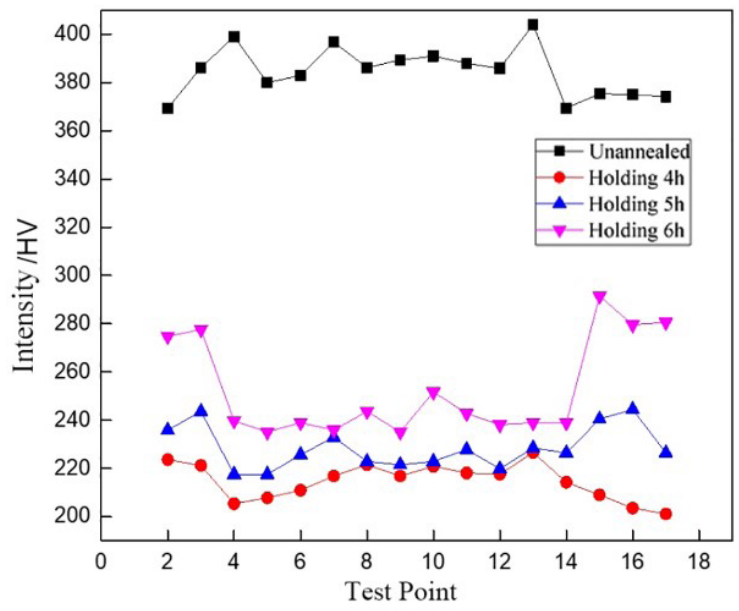

Figure 5. The curve of hardness distribution for SMAW welded joint.

CGHAZ, and the maximum hardness value is $400 H V$. From the base metal to the CGHAZ, it shows an upward trend, while the minimum hardness appears in the weld zone. The change of hardness in the weld zone is relatively stable, and there is no great fluctuation. After annealing treatment, the maximum hardness also appears near the heat-affected zone. Different from the unannealed treatment, the hardness from the base metal to the heat-affected zone shows a downward trend. Also a minimum of hardness appears in the weld zone. At the same time, the overall hardness value of the welded joint increases with the extension of the annealing and holding time, and the overall hardness value of the annealing and holding time of $6 \mathrm{~h}$ is the highest. However, with the extension of holding time, the fluctuation trend of the overall hardness distribution increases, after annealing and holding for $6 \mathrm{~h}$, the hardness distribution trend most fluctuates. This may be related to the change of microstructure and the precipitation of the second phase particles during annealing and holding.

\subsection{Effect of holding time on phase structure of joint}

Figure 6 shows the SEM morphology and EDS analysis of the weld under different annealing and holding time. As shown in Fig. 6a, the precipitated phases are mainly distributed in grain boundaries and martensite lathe boundaries in granular or rod shape. According to the EDS analysis results of region $\mathrm{A}$ in the figure, the main components of the precipitates are $\mathrm{Fe}, \mathrm{Cr}, \mathrm{Si}$ and $\mathrm{Mn}$. According to the XRD analysis results (see Figure7 and Table 3), the precipitated phase is composed of $\mathrm{Fe}-\mathrm{Cr}, \mathrm{Fe}_{3} \mathrm{Si}$, Ni-Cr-Fe, $\mathrm{Fe}_{2} \mathrm{MnAl}$ and so on. However, the precipitated phase aggregation in A zone may be caused by $\mathrm{Cr}$ enrichment, These precipitate phases are very easy to grow around $\mathrm{Cr}$-rich particles.

After $760^{\circ} \mathrm{C}+4 \mathrm{~h}$ annealing treatment, a large number of white rod-shaped precipitates appeared on the surface of the weld. As shown in area B in Figure 6b, the EDS analysis results of area $\mathrm{B}$ show that the main components of precipitated phase are $\mathrm{Fe}, \mathrm{Cr}, \mathrm{Mn}, \mathrm{V}, \mathrm{Si}, \mathrm{O}$, etc. According to the XRD analysis results (see Figure 7 and Table 3), the precipitates were mainly composed of $\mathrm{Fe}-\mathrm{Cr}, \mathrm{Fe}_{3} \mathrm{Si}_{1} \mathrm{SiO}_{2}$,
Table 3. The main precipitates in weld and base metal of P91 heat resistant steel under different holding time

\begin{tabular}{lc}
\hline State & Mainly precipitated phase \\
\hline Unannealed & $\mathrm{CrC}, \mathrm{Fe}-\mathrm{Cr}, \mathrm{Fe}_{3} \mathrm{Si}_{2} \mathrm{Fe}_{2} \mathrm{MnAl}, \mathrm{Ni}-\mathrm{Cr}-\mathrm{Fe}$ \\
\hline Holding 4h & $\mathrm{CrC}, \mathrm{Fe}-\mathrm{Cr}, \mathrm{Fe}_{3} \mathrm{Si}_{2} \mathrm{SiO}_{2}, \mathrm{Fe}_{2} \mathrm{MnAl}, \mathrm{Fe}{ }_{2}-\mathrm{V}-\mathrm{Si}, \mathrm{Fe}-\mathrm{V}$ \\
\hline Holding $5 \mathrm{~h}$ & $\mathrm{CrC}, \mathrm{Fe}-\mathrm{Cr}, \mathrm{Fe}_{3} \mathrm{Si}, \mathrm{Fe}_{2} \mathrm{MnAl}$ \\
\hline Holding 6h & $\mathrm{CrC}, \mathrm{Fe}-\mathrm{Cr}, \mathrm{Fe}_{3} \mathrm{Si}, \mathrm{Fe}_{2} \mathrm{MnAl}$ \\
\hline
\end{tabular}

$\mathrm{Fe}_{2}-\mathrm{V}$-Si. Compared with A zone, a small amount of oxides appeared at this time, part of the segregation hardened phase dissolved, and the second phase particles $\mathrm{Fe}_{2} \mathrm{~V}$-S precipitated. After the annealing treatment at $760^{\circ} \mathrm{C}+5 \mathrm{~h}$, relatively fine white granular precipitates appeared on the surface of the weld, with relatively uniform distribution, and no rod-shaped precipitates of different sizes appeared. At this time, after the annealing treatment at $5 \mathrm{~h}$, oxides and part of precipitates have been dissolved in large quantities. As shown in area $\mathrm{C}$ in Figure 6c, According to the EDS analysis results of zone $\mathrm{C}$, the main components of zone $\mathrm{C}$ are $\mathrm{Fe}, \mathrm{Cr}, \mathrm{Mn}, \mathrm{Si}$. According to the XRD analysis results (see Figure 7 and Table 3), the matrix phase is mainly composed of $\mathrm{Fe}-\mathrm{Cr}$, $\mathrm{Fe}_{3} \mathrm{Si}, \mathrm{Fe}_{2} \mathrm{MnAl}$. Compared with annealing and holding for $4 \mathrm{~h}$, the mechanical properties of the material at this time are relatively stable.

As shown in Figure $6 \mathrm{~d}$, after $760^{\circ} \mathrm{C}+6 \mathrm{~h}$ annealing and holding treatment, the precipitated phase is mainly distributed in grain boundary in granular form. In the acicular boundary of martensite and inside martensite, such precipitated particles are relatively small, which can effectively nail the grain boundary and limit the growth of martensite in the process of further thermal insulation. This well explains the reason for the fine microstructure under this condition. According to the EDS analysis results of zone $\mathrm{D}$, the main components of zone $\mathrm{D}$ are $\mathrm{Fe}, \mathrm{Cr}, \mathrm{Mn}, \mathrm{Si}$. According to the XRD analysis results, the precipitated phase is mainly composed of $\mathrm{Fe}-\mathrm{Cr}$, $\mathrm{Fe}_{3} \mathrm{Si}, \mathrm{Fe}_{2} \mathrm{MnAl}$. Compared with annealing and holding for $5 \mathrm{~h}$, the microstructure is fine and uniform, the second phase particles are dispersed, and the mechanical properties of the material are relatively excellent ${ }^{20}$.

As shown in Table 3, the main precipitates of the unannealed weld zone are $\mathrm{Fe}-\mathrm{Cr}, \mathrm{Fe}_{3} \mathrm{Si}$, $\mathrm{Fe}_{2} \mathrm{MnAl}$, Ni-Cr-Fe, which is in line with the analysis results in Figure 6a. The lat martensite structure and a large amount of precipitates of the second phase lead to a significant increase of hardness in the weld zone. During the annealing for $4 \mathrm{~h}$, the precipitation of oxide $\mathrm{SiO}_{2}$ appeared, which had a certain influence on the mechanical properties of the welded joint. However, due to the change of the microstructure of the welded joint and the disappearance of some dislocations, the hardness of the welded joint was greatly reduced.

After annealing and holding for $5 \mathrm{~h}$, a large number of oxides $\left(\mathrm{SiO}_{2}\right)$ are dissolved in the weld zone of joint. At this time, the matrix phase is strengthened and the microstructure is more uniform and fine, so the hardness is improved. After annealing and holding for $6 \mathrm{~h}$, some oxides also have been dissolved, and the precipitated phase consists of $\mathrm{Fe}-\mathrm{Cr}, \mathrm{Fe}_{3} \mathrm{Si}, \mathrm{Fe}_{2} \mathrm{MnAl}$. At this time, the precipitated phase is mainly distributed in grain boundary, martensite needle 

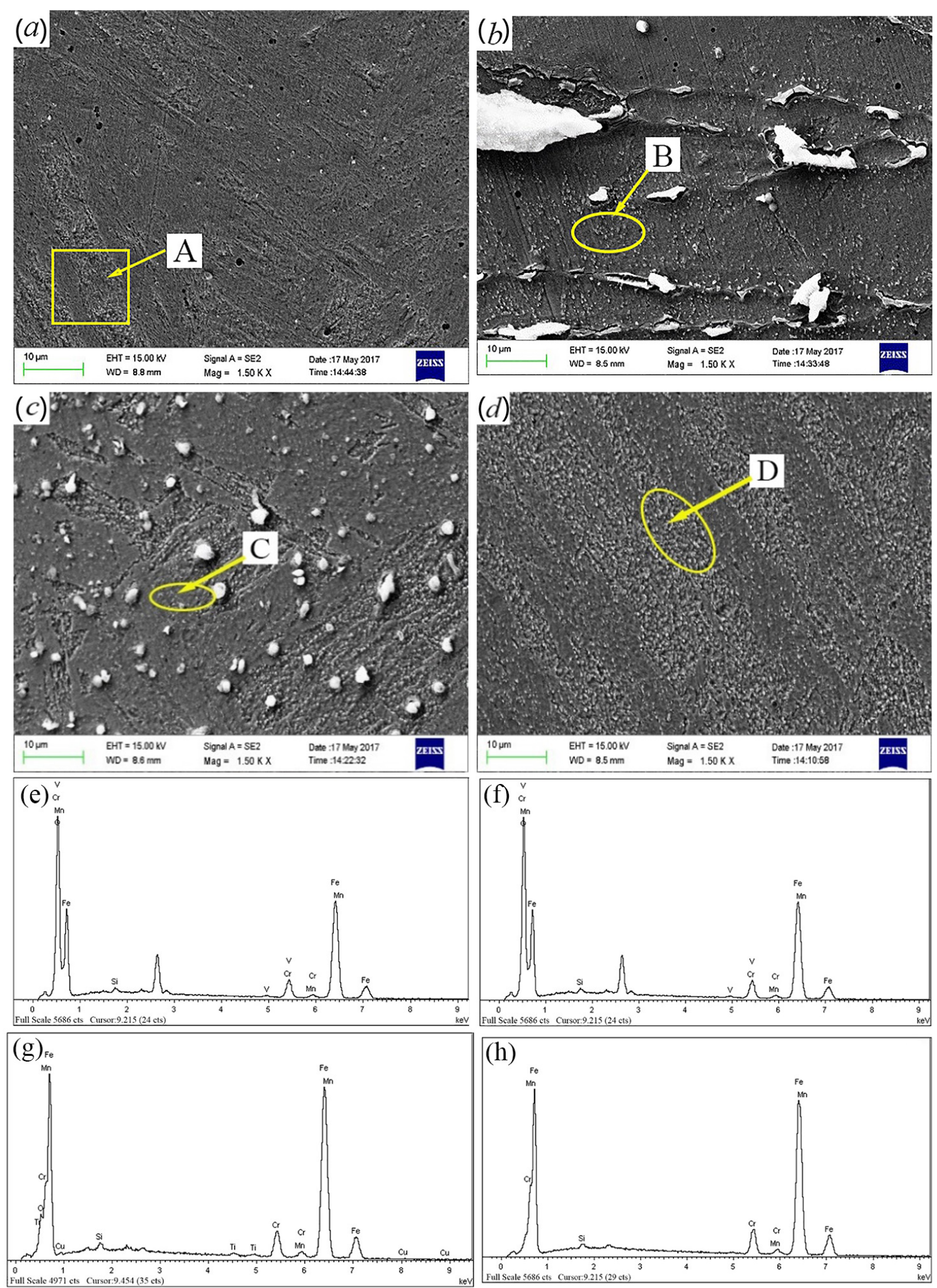

Figure 6. SEM morphology and EDS analysis in weld zone under different holding time: (a) SEM morphology of joint unannealed, (b) SEM morphology under holding 4h, (c) SEM morphology under holding 5h, (d) SEM morphology under holding 6h, (e) EDS result in A region, (f) EDS result in B region, (g) EDS result in C region, and (h) EDS result in D region. 


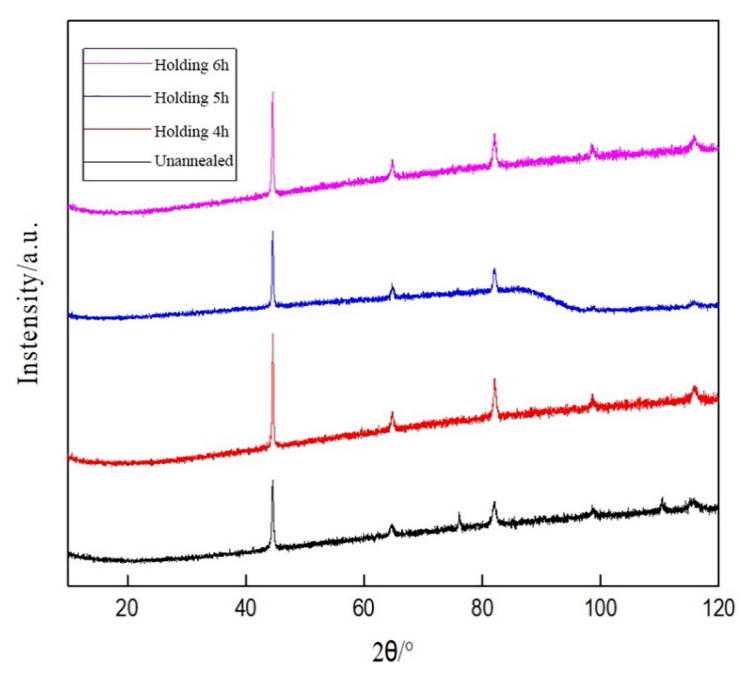

Figure 7. XRD curve of SMAW welded joint under different annealing treatment.

lamellar boundary and martensite interior in granular form, and the dislocation pinning effect is obvious. At the same time, the microstructure is relatively uniform and fine, so the mechanical properties of the welded joint are relatively excellent.

\section{Conclusions}

1. After annealing, the microstructure of CGHAZ and WZ joints changed obviously. When the holding time is $6 \mathrm{~h}$ at different annealing temperatures, the microstructure of CGHAZ and WZ zone is typical needle-like martensite, and the microstructure is relatively uniform. Compared with the microstructure after $5 \mathrm{~h}$ annealing and holding treatment, the needle-like martensite is relatively slender and the distribution is more uniform and fine. After $760^{\circ} \mathrm{C}$ annealing, the hardness of the joints is significantly lower than that before annealing. After annealing at $760^{\circ} \mathrm{C}+$ for different time, the hardness decreases from the base metal to the heat-affected zone, and the same minimum value of hardness appears in the weld zone.

2. The precipitates of the unannealed joints are mainly composed of Fe-Cr, $\mathrm{Fe}_{3} \mathrm{Si}$, Ni-Cr-Fe, $\mathrm{Fe}_{2} \mathrm{MnAl}$. After $760{ }^{\circ} \mathrm{C}+4 \mathrm{~h}$ annealing treatment, a large number of white rod-shaped precipitates appeared on the surface of the weld. At this time, there were second phase particles precipitated, accompanied by a small amount of oxides. After $760^{\circ} \mathrm{C}+5 \mathrm{~h}$ annealing treatment, relatively fine white granules appear on the surface of the weld, and the distribution is relatively uniform. After annealing at $760{ }^{\circ} \mathrm{C}+6 \mathrm{~h}$, the precipitated phase is mainly distributed in grain boundary, martensite aciculate boundary and martensite interior in granular form. The precipitated phase consists of $\mathrm{Fe}-\mathrm{Cr}, \mathrm{Fe}_{3} \mathrm{Si}, \mathrm{Fe}_{2} \mathrm{MnAl}$.

\section{Acknowledgments}

This work was financially supported by the Shandong Provincial Natural Science Foundation, China (Grant No. ZR2016JL017) and the Shandong Provincial Key Research and Development Program, China (Grant No. 2019TSLH0103)

\section{References}

1. Williams JA, Parker JD. Strain generated at austenitic: ferritic dissimilar welds during elastic pressure changes at high temperature. Mater Sci Eng A. 1995;4(1-2):242-50.

2. Zhang B, Hu Z, Wang Q, Lu C, Wang C, Jiang K. Creep rupture micro-mechanism of domestic T91 heat-resistant steel at $650^{\circ} \mathrm{C}$. Heat Treatment of Metals. 2010;35:41-6.

3. Razak NA, Davies CM, Nikbin KM. Testing and assessment of cracking in P91 steels under creep-fatigue loading conditions. Eng Fail Anal. 2017;26:320-30.

4. Hu JN, Fukahori T, Igari T, Chuman Y, Cocks ACF. Modelling of creep rupture of ferritic/austenitic dissimilar weld interfaces under mode I fracture. Eng Fract Mech. 2018;191:344-64.

5. Xiao B, Xu L, Zhao L, Jing H, Han Y, Zhang Y. Creep properties, creep deformation behavior, and microstructur-al evolution of 9Cr-3W-3Co-1CuVNbB martensite ferritic steel. Mater Sci Eng A. 2018;711:434-47.

6. Akram J, Kalvala PR, Misra M, Charit I. Creep behavior of dissimilar metal weld joints between P91 and AISI 304. Mater Sci Eng A. 2017;688:396-406.

7. Zhang R, Zhang C, Xia Z, Yang Z. Optimizing control of precipitates in T91 ferritic heat-resistant steel. Chin Shu Hsueh Pao. 2013;49(9):1075-80.

8. Pandey C, Mahapatra MM, Kumar P, Saini N. Comparative study of autogenous tungsten inert gas welding and tungsten arc welding with filler wire for dissimilar P91 and P92 steel weld joint. Mater Sci Eng A. 2018;712:720-37.

9. Dhandha $\mathrm{KH}$, Badheka VJ. Effect of activating fluxes on weld bead morphology of P91 steel bead-on-plate welds by flux assisted tungsten inert gas welding process. J Manuf Process. 2015; $17: 48-57$.

10. Divya M, Das CR, Albert SK, Goyal S, Ganesh P, Kaul R, et al. Influence of welding process on Type IV cracking behavior of P91 steel. Mater Sci Eng A. 2014;613:148-58.

11. Arivazhagan B, Sundaresan S, Kamaraj M. A study on influence of shielding gas composition on toughness of flux-cored arc weld of modified 9Cr-1Mo (P91) steel. J Manuf Process. 2009;209:5245-53.

12. Pandey C, Mahapatra MM, Kumar P, Saini N. Homogenization of P91 weldments using varying normalizing and tempering treatment. Mater Sci Eng A. 2018;710:86-101.

13. Pandey C, Mahapatra MM, Kumar P, Giri A. Microstructure characterization and charpy toughness of P91 weldment for aswelded, post-weld heat treatment and normalizing \& tempering heat treatment. Met Mater Int. 2017;23(5):900-14.

14. Pandey C, Mahapatra MM, Kumar P, Saini N, Srivastava A. Microstructure and mechanical property relationship for different heat treatment and hydrogen level in multi-pass welded P91 steel joint. J Manuf Process. 2017;28:220-34.

15. Pandey C, Mahapatra MM. Effect of groove design and post-weld heat treatment on microstructure and mechanical properties of P91 steel weld. J Mater Eng Perform. 2016;25(7):2761-75.

16. Pandey C, Mahapatra MM, Kumar P, Saini N. Effect of weld consumable conditioning on the diffusible hydrogen and subsequent residual stress and flexural strength of multipass welded P91 steels. Metall Mater Trans, B, Process Metall Mater Proc Sci. 2018;49(5):2881-95.

17. Kumar S, Pandey C, Goyal A. A microstructural and mechanical behavior study of heterogeneous P91 welded joint. Int J Press Vessels Piping. 2020;185:104128. 
18. Grybenas A, Makarevicius V, Baltusnikas A, Lukošiūtė I, Kriūkienè R. Correlation between structural changes of M23C6 carbide and mechanical behaviour of P91 steel after thermal aging. Mater Sci Eng A. 2017;696:453-60.

19. Paddea S, Francis JA, Paradowska AM, Bouchard PJ, Shibli IA. Residual stress distributions in a P91 steel-pipe girth weld before and after post weld heat treatment. Mater Sci Eng A. 2012;534:663-72.

20. Pandey C, Mahapatra MM. Evolution of phases during tempering of $\mathrm{P} 91$ steel at $760^{\circ} \mathrm{C}$ for varying tempering time and their effect on microstructure and mechanical properties. Proc Inst Mech Eng, E J Process Mech Eng. 2017;231(6):1141-61. 